\title{
Elektrocerrahi ile eksizyon sonrası cerrahi sınır pozitif yüksek dereceli servikal intraepitelyal lezyon olgularında lezyonun persistansı ile ilişkili parametreler
}

\author{
Parameters associated with persistent disease after excisional treatment by \\ electrosurgery in patients with high grade cervical intraepithelial lesion and positive \\ surgical margin
}

Derya Kılıç, Tolga Güler, Elif Avşaroğlu, Yeliz Arman Karakaya, Babür Kaleli, Erkan Alataş

Gönderilme tarihi:07.11.2020

Kabul tarihi:13.11.2020

Özet

Amaç: Yüksek dereceli servikal intraepitelyal lezyonların (HSIL) tedavisinde eksizyon sonrası cerrahi sınırda HSIL devamlılı̆ı saptanır ise yeniden eksizyon veya 4-6 ay sonra kontrol seçenekleri gündeme gelmektedir. Ancak bu olgularda re-eksizyon materyalinde HSIL'in persiste edip etmediğini öngörebilen parametreler henüz tanımlanmamıştı. Biz bu çalışmada lezyon persistansı ile ilişkili olabilecek klinik ve histopatolojik parametreleri değerlendirmeyi amaçladık.

Gereç ve yöntem: Elektrocerrahi ile eksizyonel tedavi sonrası cerrahi sınırda HSIL devamlıı̆ğı izlenen ve bu nedenle yeniden eksizyon yapılan olguların bilgileri retrospektif olarak taranmıştır. Hastaların sosyodemografik verileri, başvuru sırasındaki HPV (Human Papillomavirus) tiplemesi (HPV tip 16/18 veya diğer yüksek riskli tipler), maksimal lezyon çapları, odak sayısı, yüksek dereceli lezyonun derecesi (CIN2 veya CIN3), eksizyonel materyalin maksimal çapı, cerrahi sınır durumu ve derecelendirilmesi (Grade 1: şüpheli veya rölatif olarak tam sınırda olan cerrahi sınır pozitifliği; Grade 2: belirgin cerrahi sınır pozitifliği) ile sonraki eksizyonel işlemde HSIL'in persiste edip etmemesi analiz için kayıt edilmiştir.

Bulgular:Çalışma kriterlerine uyan toplamda 73 hasta belirlendi. Yeniden eksizyon yapılan hastaların 23 $(\% 31,5)$ tanesinde yüksek dereceli lezyonun persiste ettiği saptandı. Sosyodemografik ve histopatolojik faktörler (yaş, menapoz, sigara kullanımı, başlangıçtaki yüksek riskli HPV tipi, eksizyonun büyüklüğü, histolojik tip (CIN2/ CIN3) lezyon büyüklüğü, lezyonun odak sayısı ve cerrahi sınır pozitifliğinin derecesi) incelendiğinde, rezidüel hastalığın saptandığı ve saptanmadığı gruplar arasında istatistiksel anlamlı farklılık saptanmadı $(p=0,116$, $p=0,50, p=0,601, p=0,092, p=0,719, p=0,501, p=0,699, p=0,131, p=0,884$, sirasıyla).

Sonuç: Olguların yaklaşık üçte birinde re-eksizyon materyalinde HSIL'in persiste ettiği saptanmıştır. Ancak ne klinik özellikler ne de ilk eksizyondaki patolojik bulgular ile lezyonun varlığı arasında anlamlı bir ilişki gösterilememiştir.

Anahtar kelimeler: Servikal kanser, yüksek dereceli intraepitelyal neoplazi, cerrahi sınır, loop elektrocerrahi eksizyon prosedürü.

Kılıç D, Güler T, Avşaroğlu E, Arman Karakaya Y, Kaleli B, Alataş E. Elektrocerrahi ile eksizyon sonrası cerrahi sınır pozitif yüksek dereceli servikal intraepitelyal lezyon olgularında lezyonun persistansı ile ilişkili parametreler. Pam Tıp Derg 2021;14:167-174.

\begin{abstract}
Purpose: In the treatment of high-grade cervical intraepithelial lesions (HSIL), when HSIL is detected at the surgical margin after excision, re-excision or control after 4-6 months are the management options. However, the parameters to determine in which patients HSIL will persist in the re-excision materials are not precisely defined. In this study, we aimed to evaluate the relationship between clinical and histopathological parameters, and the persistence of the lesion after electrosurgical excision.

Materials and methods: The information of the patients who had HSIL at surgical margin after electrosurgical excisional treatment and were experienced re-excision for this reason were retrospectively investigated. In addition, the sociodemographic data of the patients, HPV (Human Papilloma Virus) typing (HPV type 16/18 or
\end{abstract}

Derya Kılıç, Dr. Öğr. Üye. Pamukkale Üniversitesi, Kadın Hastalıkları ve Doğum Anabilim Dalı, Denizli, Türkiye, e-posta: deryakilic.md@gmail. com (orcid.org/0000-0001-8003-9586) (Sorumlu Yazar)

Tolga Güler, Doç. Dr. Pamukkale Üniversitesi, Kadın Hastalıkları ve Doğum Anabilim Dalı, Denizli, Türkiye, e-posta: tolgaguler@yahoo.com (orcid.org/0000-0001-6673-8604)

Elif Avşaroğlu, Arş. Gör. Pamukkale Üniversitesi, Kadın Hastalıkları ve Doğum Anabilim Dalı, Denizli, Türkiye, e-posta: elifavsaroglu_@hotmail. com (orcid.org/0000-0001-8340-7831)

Yeliz Arman Karakaya, Dr. Öğr. Üye. Pamukkale Üniversitesi, Patoloji Anabilim Dalı, Denizli, Türkiye, e-posta: yelizkarakaya20@gmail.com (orcid.org/0000-0002-6669-9972)

Babür Kaleli, Prof. Dr. Pamukkale Üniversitesi, Kadın Hastalıkları ve Doğum Anabilim Dalı, Denizli, Türkiye, e-posta: bkaleli@aol.com (orcid. org/0000-0002-5122-9329)

Erkan Alataş, Prof. Dr. Pamukkale Üniversitesi, Kadın Hastalıkları ve Doğum Anabilim Dalı, Denizli, Türkiye, e-posta: erkanalatas@hotmail.com (orcid.org/0000-0001-6423-5106) 
other high risk types) at the time of admission, maximal lesion diameter, number of foci, degree of high-grade lesion (CIN2 or CIN3), maximal diameter of excisional material, surgical margin status and grading (Grade 1: suspicious or relatively borderline surgical margin positivity; Grade 2: significant surgical margin positivity), and persistence of HSIL in the subsequent excisional procedure were recorded for analysis.

Results: 73 patients who met the inclusion criteria of the study were identified. High-grade lesions were found to persist in $23(31.5 \%)$ patients who underwent re-excision. When sociodemographic and histopathological factors were analyzed (age, menopause, smoking, initial high-risk HPV type, size of excision, histological type (CIN2/CIN3) lesion size, lesion focus number, and the degree of surgical margin positivity), no statistical significance was found between the groups with and without residual disease $(p=0.116, p=0.750, p=0.601$, $p=0.092, p=0.719, p=0.501, p=0.699, p=0.131, p=0.884$, respectively).

Conclusions: HSIL is found to be persisted in approximately one third of the cases with positive surgical margin after re- excision. However, neither clinical features nor pathological findings at the first excision were found to be significantly related with persistence.

Key words: Cervical cancer, high-grade intraepithelial neoplasia, surgical margin, loop electrosurgical excision procedure.

Kılıc D, Guler T, Avşaroglu E, Arman Karakaya Y, Kaleli B, Alatas E. Parameters associated with persistent disease after excisional treatment by electrosurgery in patients with high grade cervical intraepithelial lesion and positive surgical margin. Pam Med J 2021;14:167-174.

\section{Giriş}

Serviks kanseri gerek tarama stratejileri gerekse de aşılama programları ile önlenebilir bir kanser türüdür. Ancak halen tüm kadın kanserleri arasında sıklık ve mortalite açısından dördüncü sırada yer alır [1]. Serviks kanserinin tarama stratejisi erken kanser tanısına ek olarak kansere progresyonun önlenmesi amacıyla yüksek dereceli servikal intraepitelyal lezyonların (HSIL) erken tanısı temelinde oluşturulmuştur. Saptanan yüksek dereceli lezyonların tanısı ve tedavisi ise eksizyonel prosedürler ile yapılmaktadır. Ancak eksizyonel tedavi sonrası bile \%30'lara varan yüksek oranlarda persistans ve/veya rekürrens oranları bildirilmektedir [2]. Bu olgularda ayrıca tedaviye rağmen normal populasyona göre servikal kanser gelişimi açısından yaklaşık 5 kat artmış risk olduğu unutulmamalıdır [2, 3].

Hastalığın persistansı ve/veya rekürrensi açısından; yaş, multiparite, Human Papillomavirus (HPV) persistansı, yüksek dereceli lezyonun büyüklüğü, eksizyon büyüklüğü ve cerrahi sınır pozitifliği olası risk faktörleri arasında sayılabilir [4, 5]. Risk faktörlerinin değerlendirildiği iki kapsamlı metaanalizin sonuçları özellikle pozitif cerrahi sınır varlığının persistan veya rekürren hastalığın güçlü bir prediktörü olduğu yönündedir [6, 7]. Ancak eksizyonel prosedür sonrası cerrahi sınırda HSIL devamlıı̆̆ı saptanan olguların nasıl yönetileceği halen güncel bir tartışma konusudur. Bu durumda re-eksizyon veya 4-6 ay sonra değerlendirilmek üzere takip yönetim seçenekleri arasında gündeme gelmektedir [8].

De Oliveria ve ark. [6] yaptığı metaanalizde, pozitif cerrahi sınır varlığında takip yerine reeksizyon yapılan olguların \%52,3 (23/44)'ünde rezidüel lezyon saptandığı bildirilmiştir. Yani olguların yarısında re-eksizyon materyalinde cerrahi sınır pozitif olmasına rağmen rezidüel lezyon saptanmamıştır. Bu sonuç tekrarlayan eksizyonel prosedürlerin oluşturduğu obstetrik komplikasyonlar da göz önüne alınırsa reeksizyon yerine 4-6 ay sonra değerlendirilmek üzere takip kararını ön plana çıkarmaktadır [9].

Nitekim Amerikan Kolposkopi ve Servikal Patoloji Derneği (ASCCP) eksizyonel tedavi sonrası cerrahi sınır pozitif HSIL olgularında 4-6 ay sonra sitolojik ve endoservikal küretaj ile incelemeyi önerirken tanı amaçlı re-eksizyonun da uygulanabilirliğini kabul etmektedir [8]. Hatta tekrarlayan eksizyonel prosedürler açısından hasta uygun değil ise tedavi seçenekleri arasında histerektomiye de yer vermektedir. Ancak ASCCP bile hangi hastaların diagnostik eksizyonel prosedürler için hangi hastaların ise takip açısından daha uygun olduğunu net olarak sınıflandıramamaktadır. Hastalarda reeksizyon sonrası yüksek dereceli lezyonun persiste ettiğini predikte edebilen parametreler tanımlanmış değildir.

Biz burdan yola çıkarak bu çalışmada, HSIL tedavisi amacı ile kliniğimizde elektrocerrahi ile eksizyon yapılan ve cerrahi sınırda yüksek dereceli lezyon saptanan olgulardaki klinik 
ve histopatolojik veriler ile rezidüel hastalığın varlığı arasındaki ilişkiyi araştırmayı ve risk faktörlerini tanımlamayı amaçladık.

\section{Gereç ve yöntem}

Kanser erken tanı programı neticesinde 2016-2020 yılları arasında Pamukkale Üniversitesi'ne yüksek riskli HPV-DNA pozitifliği saptanması üzerine refere edilen ve kolposkopik biyopsi ile konfirme edilmiş HSIL tanısı alan hastalar retrospektif olarak tarandı. Çalışma için Pamukkale Üniversitesi Tıp Fakültesi Girişimsel Olmayan Klinik Araştırmalar Etik Komitesi'nden izin alındı.

Başvuru anında hastaların mevcut HPV subtipleri HPV 16 ve/veya 18 ve diğer olmak üzere iki ana kategoriye ayrıldı. Başvuru anında Pap smear test sonuçları; benign bulgular, önemi belirlenemeyen atipik skuamoz hücreler (ASCUS), atipik glandüler hücreler (AGC), düşük dereceli intraepitelyal lezyon (LSIL) ve yüksek dereceli intraepitelyal lezyon (HSIL) olarak sınıflandırıldı. Kolposkopi bulguları ve nihai histopatolojik sonuçları benign bulgular, düşük dereceli skuamöz intraepitelyal lezyon/ LSIL (CIN I) ve yüksek dereceli intraepitelyal lezyon/HSIL (CIN II/III) olmak üzere üç kategoride incelendi. Yüksek dereceli servikal lezyon saptanan olguların klinik özellikleri, kolposkopik bulguları ve sosyodemografik özelliklerine dosya kayıtları üzerinden ulaşıldı.

Kliniğimizde hastaların rutin takip ve tedavileri güncel rehberlerle ve tarama stratejisi ile uygun olarak yapılmaktadır [8]. Kolposkopik muayeneler 40 kat büyütme özelliğine sahip, dijital bir ekrana bağlı, yeşil filtre özelliğine sahip, binoküler kolposkop ile gerçekleştirilmektedir. Kolposkopi uygulama protokolümüze uygun olarak, serviks serum fizyolojik ile yıkandıktan sonra atipik damarlanma açısından yeşil filtre ile taranmakta, sonrasında servikse \%3 konsantrasyonda asetik asit uygulanmaktadır. Bir dakikalık uygulama sonrası serviks aseto-white görünüm açısından tarandıktan sonra Lugol solüsyonu ile boyanarak, Lugol tutulumu olmayan alanlar not edilmektedir. Şüpheli alanlardan biyopsi alınmakta, biyopsi sonuçlarından en yüksek dereceli lezyon, hastanın patoloji sonucu olarak değerlendirilmektedir.

Kolposkopik biyopsi ile konfirme edilmiş HSIL tanısı konularak eksizyonel prosedür uygulanan hastalar çalışmaya dahil edildi. Uygulanan cerrahi prosedürü standardize edebilmek amacı ile hastalığın tedavisi için sadece elektrocerrahi ile eksizyon uygulanan hastaların dahil edildi. Çalışmaya dahil edilen tüm hastalarda cerrahi sınır pozitifti ve eksizyon sonrası bu endikasyonla 30-45 gün içinde re-eksizyon yapılmıştı. Soğuk konizasyon uygulanan, cerrahi sınır negatif olan, cerrahi sınır pozitif olmasına rağmen rekonizasyon yapılmayarak 4-6 ay sonra kontrole çağrılarak takip edilen olgular çalışma dışı bırakıldı.

Olguların tümünün patoloji preparatları yeniden değerlendirildi ve cerrahi sınır pozitifliği göreli olarak iki alt gruba ayrıldı (Grade 1: şüpheli veya rölatif olarak tam sınırda olan cerrahi sınır pozitifliği, Grade 2: belirgin cerrahi sınır pozitifliği;). Bunun yanında hastaların başvuru sırasındaki HPV (Human Papilloma Virus) tiplemesi (HPV tip 16/18 veya diğer yüksek riskli tipler), yaşları, maksimal lezyon çapları, odak sayısı, yüksek dereceli lezyon tipi (CIN2 veya CIN3), eksizyonel materyalin maksimal çapı, cerrahi sınır durumu ve göreli gradelenmesi, sonraki eksizyonel işlemde yüksek dereceli lezyonun sebat edip etmemesi analiz için kayıt altına alındı.

\section{İstatistiksel yöntem}

Nicel sürekli değişkenlerin (yaş gibi) tanımsal değerleri standart tanımlayıcı istatistiksel yöntemlerle incelendi (aritmetik ortalama, standart sapma, medyan). Kategorik değişkenler (varlık sıklıkları) frekansları ve toplam içindeki yüzdeleri ile birlikte verildi. Nicel ölçümlerin değerlendirilmesi, verilerin dağılım özelliklerine göre, "Student's $t$ test" veya "Wilcoxon signed rank test" kullanılarak yapıldı. Kategorik değişkenlerin kıyaslamaları, olgu dağılımlarının durumuna göre Chi-square ya da Fischer's Exact Test ile yapıldı. $P$ değeri $<0,05$ olan durumlar istatistiksel olarak anlamlı kabul edildi.

\section{Bulgular}

Çalışma kriterlerine uyan toplamda 73 hasta belirlendi. Çalışmaya dahil olma kriterleri ile uyumlu olarak olguların tümünde ilk eksizyon materyalinde HSIL cerrahi sınırda devam etmekteydi ve tüm hastalara bu nedenle reeksizyon yapılmışı. Hastaların ortalama yaşı $45,2 \pm 8,9$ idi. Hastaların 23 tanesinde $(\% 31,5)$ HSIL'in eksize edilen dokuda persiste ettiği, 
50 'sinde (\%68) ise persiste etmediği saptandı. Her iki grup birbiri ile karşılaştırıldığında yaş, parite, ilk koit yaşı, oral kontraseptif kullanımı, sigara kullanımı ve menapozal durum ile ilgili gruplar arasında anlamlı farklılık izlenmedi ( $p=0,116, p=0,852, p=0,366, p=0,741, p=0,601$, $p=0,75$ sırasıyla). Tüm olguların demografik verileri ve medikal öykülerinin re-eksizyon materyalinde HSIL persistansı ile ilişkisi Tablo 1 'de sunulmuştur.

Histopatolojik olarak HSIL tanısı almış olan tüm olgular analiz edildiğinde toplamda $37(\% 50,6)$ kadında taramada HPV tip 16 ve/veya 18 pozitif bulunduğu, $36 \quad(\% 50,4)$ kadında diğer tip yüksek tipli HPV pozitifliği olduğu izlendi. Yine bu olguların toplamda 45 (\%61,6)'inin CIN2 tanısı, $28(\% 38,3)$ 'inin ise CIN3 tanısı aldığı saptandı. HSıL'in persiste ettiği olguların histopatolojik özelliklerinin reeksizyon materyalinde HSIL persistansı ile ilişkisi Tablo 2'de sunulmuştur. Histopatolojik risk faktörleri arasında yer alan eksizyonun büyüklüğü, histolojik tip (CIN2/CIN3) lezyon büyüklüğü, lezyonun odak sayısı ve cerrahi sınır pozitifliğinin derecesini $(p=0,719, p=0,501$, $p=0,699, p=0,131, p=0,884$, sırasıyla) rezidüel hastalığın saptandığı ve saptanmadığı gruplar arasında karşılaştırdığımızda, gruplar arası istatistiksel anlamlı farklılık saptanmadı.

\section{Tartışma}

$\mathrm{Bu}$ çalışmaya dahil edilen 73 hastanın 23 (\%32)'ünde re-eksizyon materyalinde HSIL'in persiste ettiği izlenirken, hastaların 50 (\%68) 'sinde re-eksizyon materyalinde HSIL'in persiste etmediği izlenmiştir. Bu sonuç özellikle genç olguların yönetiminde tekrarlayan eksizyonel prosedürlerin oluşturduğu obstetrik komplikasyonlar da göz önüne alınırsa re-eksizyon yerine 4-6 ay sonra tekrar değerlendirmek üzere takip kararını ön plana çıkarmaktadır [9].

Servikal kanser gelişimi açısından yüksek riskli grupta yer alan bu hastaların en güvenli şekilde monitorizasyonunu sağlayabilmek için kendi içinde ayrıca risk analizine intiyaç duyulmaktadır. Ancak özellikle primer eksizyonel tedavi sonrası rezidüel hastalığı predikte edebilen faktörleri araştıran literatürde yeteri kadar çalışma mevcut değildir. Biz çalışmamızda cerrahi sınır pozitifliği nedeni ile re-eksizyon yapılan hastaları rezidü lezyon olan ve rezidü lezyon olmayan olmak üzere iki gruba ayırarak inceledik. Olası klinik ve histopatolojik risk faktörleri arasında yer alan; yaş, menapoz, sigara kullanımı, başlangıçtaki yüksek riskli HPV tipi, eksizyonun büyüklüğü, histolojik tip (CIN2/CIN3) lezyon büyüklüğü, lezyonun odak sayısı ve cerrahi sınır pozitifliğinin derecesini

Tablo 1. Olguların demografik verileri ve medikal öyküsünün re-eksizyon materyalinde yüksek dereceli lezyonun persistansı ile ilişkisi

\begin{tabular}{lllll}
\hline & $\begin{array}{l}\text { Yüksek dereceli } \\
\text { lezyon } \\
\text { persiste etmiyor } \\
(\mathbf{n = 5 0 )}\end{array}$ & $\begin{array}{l}\text { Yüksek dereceli } \\
\text { lezyon } \\
\text { persiste ediyor } \\
\mathbf{( n = 2 3 )}\end{array}$ & $\boldsymbol{p}$ & $\begin{array}{l}\text { Toplam } \\
(\mathbf{n = 7 3 )}\end{array}$ \\
\hline Yaş (yıl) & 46,3 & 42,6 & 0,116 & $45,2 \pm 8,9$ \\
Parite & $2,1 \pm 1,1$ & $2,1 \pm 1,2$ & 0,852 & $2,1 \pm 1,1$ \\
İlk koital yaş & $20,5 \pm 4,2$ & $19,6 \pm 3,8$ & 0,366 & $20,2 \pm 4,1$ \\
Oral kontraseptif & & $20(\% 32,8)$ & 0,741 & $61(\% 100)$ \\
Hayır & $41(\% 67,2)$ & $3(\% 75)$ & $12(\% 100)$ \\
Evet & $9(\% 75)$ & $14(\% 29,2)$ & 0,601 & $48(\% 100)$ \\
Sigara kullanımı & & $9(\% 36,0)$ & $25(\% 100)$ \\
Hayır & $34(\% 70,8)$ & & & \\
Evet & $16(\% 64,0)$ & $18(\% 39,1)$ & $46(\% 100)$ \\
Menapoz & & $5(\% 18,5)$ & $73(\% 100)$ \\
\hline Hayır & $28(\% 60,9)$ & & \\
Evet & $22(\% 81,5)$ & & & \\
\hline
\end{tabular}


Tablo 2. Olguların klinik ve patolojik özelliklerinin re-eksizyon materyalinde yüksek dereceli lezyonun persistansı ile ilişkisi

\begin{tabular}{|c|c|c|c|c|}
\hline & $\begin{array}{l}\text { Yüksek dereceli lezyon } \\
\text { persiste etmiyor } \\
(n=50)\end{array}$ & $\begin{array}{l}\text { Yüksek dereceli lezyon } \\
\text { persiste ediyor }(n=23)\end{array}$ & $\begin{array}{l}\text { Toplam } \\
(n=73)\end{array}$ & $p$ \\
\hline \multicolumn{5}{|l|}{ HPV16/18 } \\
\hline negatif & $28(\% 77,8)$ & $8(\% 22,2)$ & $36(\% 100)$ & 0,092 \\
\hline pozitif & $22(\% 59,5)$ & $15(\% 40,5)$ & $37(\% 100)$ & \\
\hline \multicolumn{5}{|l|}{ İlk eksizyon } \\
\hline$<20 \mathrm{~mm}$ & $24(\% 70,6)$ & $10(\% 29,4)$ & $34(\% 100)$ & 0,719 \\
\hline$\geq 20 \mathrm{~mm}$ & $26(\% 66,7)$ & $13(\% 33,3)$ & $39(\% 100)$ & \\
\hline \multicolumn{5}{|l|}{ Histolojik tanı } \\
\hline CIN2 & $33(\% 73,3)$ & $12(\% 26,7)$ & $45(\% 100)$ & 0,501 \\
\hline CIN3 & $17(\% 60,7)$ & $11(39,3)$ & $28(\% 100)$ & \\
\hline \multicolumn{5}{|l|}{ Odak sayısı } \\
\hline 1 & $45(\% 69,2)$ & $20(\% 39,8)$ & $65(\% 100)$ & 0,699 \\
\hline$>1$ & $5(\% 62,5)$ & $3(\% 37,5)$ & $8(\% 100)$ & \\
\hline $\begin{array}{l}\text { Lezyon boyutu } \\
(\mathrm{mm})\end{array}$ & 0,30 & 0,49 & & 0,131 \\
\hline \multicolumn{5}{|l|}{ Sınır durumu } \\
\hline Grade1 & 27 & 12 & $39(\% 100)$ & 0,884 \\
\hline Grade2 & 23 & 11 & $34(\% 100)$ & \\
\hline
\end{tabular}

rezidüel hastalığın saptandığı ve saptanmadığı gruplar arasında karşılaştırdığımızda, gruplar arası istatistiksel anlamlı farklılık saptamadık.

Servikal kanser tarama programında, karsinogenez gelişmeden önce yüksek dereceli lezyonların yakalanması ve tedavisi temel hedeflerdendir. Ancak persistans ve/ veya rekürrens oranlarının cerrahi sınır negatif olan hastalara göre yüksek olduğu olarak saptanmasına rağmen pozitif cerrahi sınırı olan hastaların yönetimi halen tartışmalıdır [2, 10]. Oysa bu olguların tanı sonrası prospektif takip sonuçları da birikip analiz edildiğinde, preinvaziv ve invaziv kanser gelişimi açısından riskler daha hassas olarak değerlendirilebilecek ve tarama programında modifikasyonlar gündeme gelebilecektir. Literatürde başlangıç konizasyonu sonrası tekrarlayan eksizyonlarda rezidüel hastalık oranı \%44-84'ler civarında bildirilmektedir [11] Çalışma grubumuzda biz bu oranı \%32 olarak daha düşük saptadık. Cerrahi sınır pozitif olmasına rağmen erken dönemde reeksizyon materyalinde lezyon izlememiz yapılan cerrahi müdahaleye sekonder inflamasyon ilişkili iyileşme süreci ile ilişkili olabilir [12].

ATHENA (Addressing the Need for Advanced HPV Diagnostics) çalışması ile birlikte prevalansı yüksek olan HPV 16 ve/veya HPV 18 bulunan olgularda servikal prekanseröz lezyonların diğer yüksek riskli HPV'lere göre daha sık bulunduğu gösterilmiştir [13]. Diğer HPV ayrıntılı genotiplerini saptamanın önemi net olarak gösterilmese de güncel kılavuzlar 30 yaşın üstünde olan kadınlarda sitolojisi anormal ise HPV DNA'sı pozitif olan hastalara kolposkopi yapılmasını önermektedir [8, 14]. Türkiye de bununla uyumlu olarak, daha etkin bir tarama programına geçebilmek amacıyla 2014 yılında Ulusal kanser HPV bazlı tarama programını başlattı [15]. Dört milyon kadını içeren Türkiye 
verilerine baktığımız zaman ise HPV 16/18'in yanısıra sıklık sırasına göre HPV tip 33, 31, 35 ve 45 'in de önemli olduğunun üzerine vurgu yapıldığını görmekteyiz [14]. Tüm bu alt tipler için; HPV DNA analizinin bu çalışmada, $\geq$ CIN2 için \%10'u aşan pozitif prediktif değer gösterdiği bildirilmiştir. Bu bulguyu destekleyen benzer çalışmalar da mevcuttur [16]. 16/18 dışı HPV enfeksiyonunun geniş genotipleme ile HSIL ve üzeri lezyonlar ile ilişkisinin belirlenmesi amacı ile geniş kapsamlı çalışmalara intiyaç duyulmaktadır. Çalışmamızda $73 \mathrm{HSIL}$ tanılı olgunun 36'sında HPV 16/18 negatif, diğer yüksek riskli HPV tipleri pozitifti. HPV tip 16/18 ve diğer yüksek riskli HPV tipleri arasında rezidüel lezyonun sebat etmesi açısından gruplar arasında anlamlı risk artışı saptamadık.

Kawano ve ark. [4] HSIL nedeni ile konizasyon yapılan 300 olguyu cerrahi sınır pozitifliği ile ilgili risk faktörlerini araştırmak amacı ile incelediler. Bu çalışmada hastaların $75^{\prime}$ inde cerrahi sınır pozitifliği mevcuttu. Cerrahi sınır pozitifliği için risk faktörlerini multivaryant analizle inceledikleri zaman preoperatif anormal sitolojinin $(p=0,001), 2$ veya daha fazla kadranda lezyon tespit edilmesinin $(p=0,011)$, kon uzunluğunun kısa olmasının $(p<0,001)$ cerrahi sınır pozitifliği açısından risk faktörleri olduğunu tespit ettiler. Çalışmanın sonucu olarak 40 yaşın altındaki kadınlarda tek odak varlığında $15 \mathrm{~mm}$, multiple odak varlığında ise $20 \mathrm{~mm}$ uzunlukta konizasyon yapılmasını önerdiler. Ancak bu çalışmada olduğu gibi cerrahi sınır pozitifliği ile ilişkili faktörleri inceleyen çok sayıda çalışma olmasına rağmen, cerrahi sınır pozitifliği olan hastalarda rezidüel hastalıkla ilişkili risk faktörlerini inceleyen yeterli veri yoktur. Kawano ve ark.'nın [4] cerrahi sınır pozitifliği açısından riskli bulduğu parametreleri (sitoloji, kon boyutu, multiple odak varlığı) re-eksizyon materyalinde rezidü lezyon varlığı açısından karşılaştırdığımızda çalışmamızda gruplar arasında anlamlı farklılık saptamadık.

Tasci ve ark. [12] çalışmamıza benzer şekilde cerrahi sınır pozitif HSIL olgularında re-eksizyon materyallerini inceleyerek rezidüel hastalığı predikte edebilecek risk faktörlerini araştırdılar. Çalışma kapsamında 74 hastayı retrospektif olarak incelediler. Çalışma grubundaki yetmiş dört hasta içerisinde $34 \quad(\% 45,9)$ hastada rezidüel hastalık mevcuttu. Eksizyon yöntemi, konun bazal alanı, yüksekliği, endoservikal marjin, glandüler tutulum ve odak sayısı reeksizyon materyalinde rezidüel hastalık olan ve olmayan grupta karşılaştıııldı. Çalışmanın sonucuna göre sadece çoklu odak sayısı rezidüel hastalığı predikte edebilmekteydi (\%41 tek odak varlığında, \%80 iki veya daha fazla odak varlığında, $p=0,02$ ). Bizim çalışmamızda bu çalışmadan farklı olarak her iki grup arasında odak sayısı açısından da anlamlı fark bulmadık. Çoklu odak tutulumu ve konizasyon büyüklüğünün ise bizim çalışmamızda da olduğu gibi rezidüel hastalığı tahmin edemediğini bildiren farklı çalışmalar da mevcuttur [17]. Tasci ve ark. [12] yaptıkları çalışmada aynı zamanda başlangıç patolojileri HSIL olan olguların \%4,9'unda re-eksizyon materyalinde mikroinvaziv karsinom saptamışlardır. Bu sonuç bu olguların yönetiminde aşırı tedavi yapmadan güvenli yolun seçilmesi ile ilgili standardizasyon intiyacını ortaya koymaktadır. Biz çalışmamızda re-eksizyon materyallerinin hiçbirinde mikroinvaziv veya invaziv kanser saptamadık.

Fu ve ark. [18] benzer şekilde HSIL saptanması üzerine eksizyonel prosedür uygulanan cerrahi sınır pozitifliği nedeni ile reeksizyon yapılan 145 hastayı retrospektif olarak inceledi. Çalışmalarında bizim çalışmamızdaki oranlara benzer şekilde olguların \%34,2'sinde rezidüel hastalık tespit ettiler. Bu olguların 5 tanesinde invaziv servikal kanser, 31 tanesinde CIN3, 9 tanesinde CIN2, 2 tanesinde CIN1 mevcuttu. Multivaryant analiz ile risk faktörleri incelendiğinde rezidüel hastalığın prediktörleri olarak yaş $(\geq 35)(p=0,033)$, major anormal sitoloji $(p=0,002)$, ve konizasyon öncesi yüksek riskli HPV pozitifliği viral yükün $\geq 300 \mathrm{RLU}$ (relative light units) $(p=0,011)$ olarak saptandı [18]. Benzer şekilde, Ayhan ve ark. [19] smearde major anormalliklerin (ASC-H, HSIL ve SCC) saptanmasının rezidüel hastalık açısından anlamlı risk oluşturduğunu bildirmişlerdir. Biz çalışmamızda ise anormal sitoloji varlığı açısından her iki grup arasında anlamlı farklılık saptamadık. Gruplar arası başlangıç sitoloji sonuçları Şekil 1'de gösterilmiştir.

Sınılı hasta sayısı ve retrospektif dizaynı çalışmamızın limitasyonları arasında yer almaktadır. Tek merkez olması, temel sosyodemografik verileri dışında daha ayrıntılı klinik verilerinin analize dahil edilmesi ve tüm hastalara aynı eksizyonel prosedürün aynı teknikle uygulanmış olması ise güçlü yanlarıdır. 


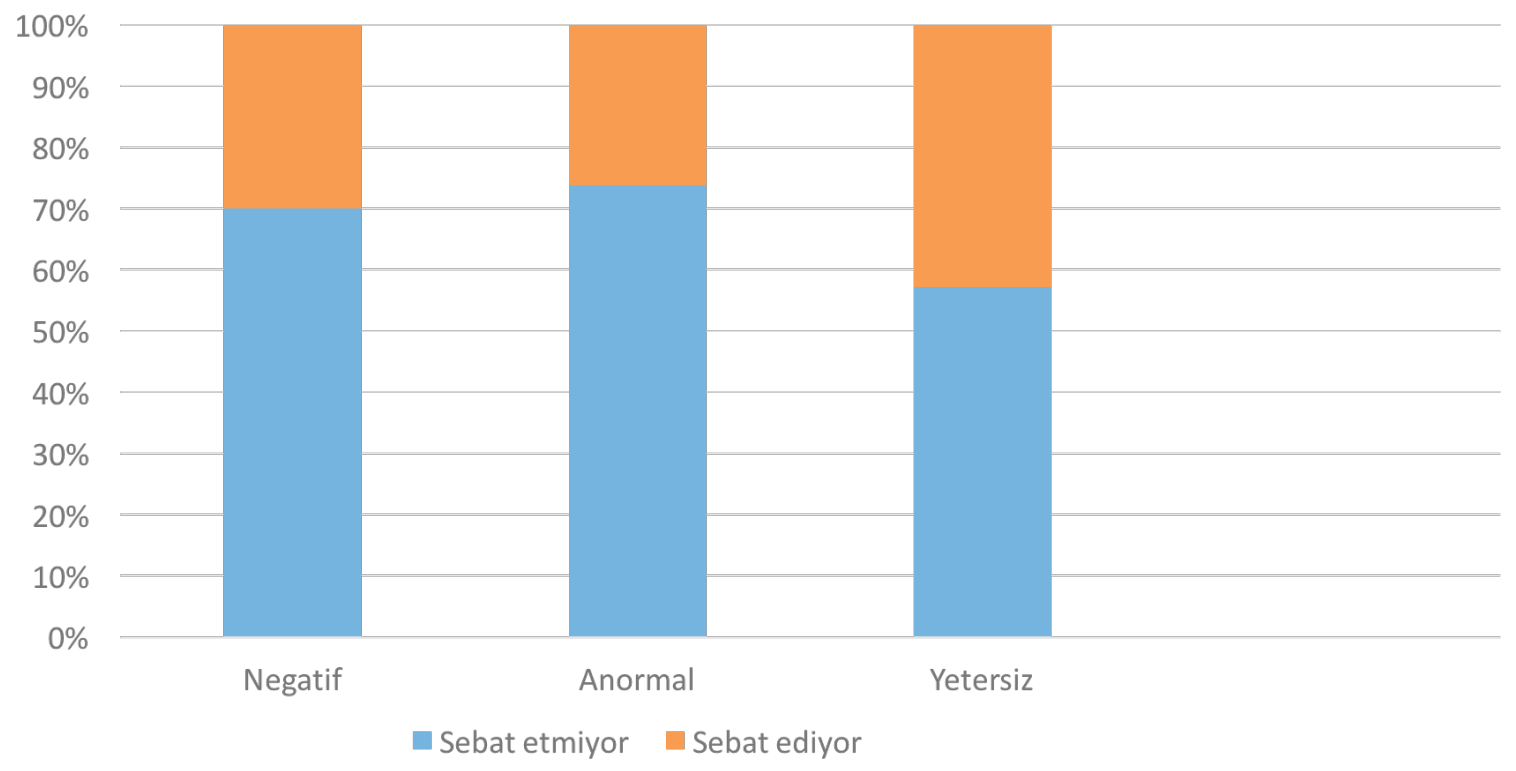

Şekil 1. Olguların başlangıç smear sonuçlarının yüksek dereceli lezyonun persistansı ile ilişkisi

Sonuç olarak cerrahi sınır pozitifliği rezidüel/ rekürren hastalık için en güçlü prediktörlerden birisidir [20]. Bununla birlikte, pozitif cerrahi sınırlı hastaların yönetimi tartışmalıdır. Hangi hastalarda lezyonun persiste ettiğini predikte edebilecek risk faktörleri henüz tanımlanmamıştır. Bu çalışmada yeniden eksizyon sonrası cerrahi sınır pozitif saptanan olguların yaklaşık üçte birinde yüksek dereceli lezyonun persiste ettiği saptanmıştır. Ancak ne klinik özellikler ne de ilk eksizyondaki patolojik bulgular ile persistans arasında anlamlı bir ilişki gösterilememiştir. Çalışmamızda incelediğimiz olası risk faktörleri arasında yer alan yaş, başlangıçtaki yüksek riskli HPV tipi, eksizyonun büyüklüğü, histolojik tip (CIN2/CIN3) lezyon büyüklügü, lezyonun odak sayısı ve cerrahi sınır pozitifliğinin derecesi gibi parametrelerin takipteki önemi ise belirsizdir. Servikal kanser tarama programında yüksek riskli grupta yer alan bu hastaların takip ve tedavi protokollerinin oluşturulabilmesi için ileri çalışmaların sonuçlarının birbiri ile karşılaştırılması gerekmektedir.

Çıkar ilişkisi: Yazarlar çıkar ilişkisi olmadığını beyan eder.

\section{Kaynaklar}

1. Bray F, Ferlay J, Soerjomataram I, Siegel RL, Torre LA, Jemal A. Global cancer statistics 2018: GLOBOCAN estimates of incidence and mortality worldwide for 36 cancers in 185 countries. CA Cancer J Clin 2018;68:394-424. https://doi.org/10.3322/caac.21492
2. McCredie MRE, Sharples KJ, Paul C, et al. Natural history of cervical neoplasia and risk of invasive cancer in women with cervical intraepithelial neoplasia 3: a retrospective cohort study. Lancet Oncol 2008;9:425434. https://doi.org/10.1016/S1470-2045(08)70103-7

3. Dos Santos Melli PP, Duarte G, Quintana SM. Multivariate analysis of risk factors for the persistence of high-grade squamous intraepithelial lesions following loop electrosurgical excision procedure. Int J Gynaecol Obstet 2016;133:234-237. https://doi.org/10.1016/j. ijgo.2015.09.020

4. Kawano K, Tsuda N, Nishio S, et al. Identification of appropriate cone length to avoid positive cone margin in high grade cervical intraepithelial neoplasia. J Gynecol Oncol 2016;27:e54. https://doi.org/10.3802/ jgo.2016.27.e54

5. Andrade CEMC, Scapulatempo Neto $C$, Longatto Filho A, et al. Prognostic scores after surgical treatment for cervical intraepithelial neoplasia: a proposed model and possible implications for post-operative follow-up. Acta Obstet Gynecol Scand 2014;93:941-948. https:// doi.org/10.1111/aogs.12446

6. De Oliveira CA, Russomano FB, Gomes Júnior SC dos S, Corrêa F de M. Risk of persistent high-grade squamous intraepithelial lesion after electrosurgical excisional treatment with positive margins: a metaanalysis. Sao Paulo Med J 2012;130:119-125. https:// doi.org/10.1590/s1516-31802012000200009

7. Ghaem Maghami S, Sagi S, Majeed G, Soutter WP. Incomplete excision of cervical intraepithelial neoplasia and risk of treatment failure: a meta-analysis. Lancet Oncol 2007;8:985-993. https://doi.org/10.1016/S14702045(07)70283-8 
8. Massad LS, Einstein MH, Huh WK, et al. 2012 updated consensus guidelines for the management of abnormal cervical cancer screening tests and cancer precursors. Obstet Gynecol 2013;121:829-846. https://doi. org/10.1097/AOG.0b013e3182883a34

9. Simoens C, Goffin F, Simon P, et al. Adverse obstetrical outcomes after treatment of precancerous cervical lesions: a Belgian multicentre study. BJOG 2012;119:1247-1255. https://doi.org/10.1111/j.14710528.2012.03429.x

10. Kilic D, Guler T, Atigan A, et al. Predictors of Human papillomavirus (HPV) persistence after treatment of high grade cervical lesions; does cervical cytology have any prognostic value in primary HPV screening? Ann Diagn Pathol 2020;49:151626. https://doi. org/10.1016/j.anndiagpath.2020.151626

11. Miyoshi $\mathrm{Y}$, Miyatake $\mathrm{T}$, Ueda $\mathrm{Y}$, et al. Prediction, based on resection margins, of long-term outcome of cervical intraepithelial neoplasia 3 treated by Shimodaira-Taniguchi conization. Arch Gynecol Obstet 2012;285:1427-1432. https://doi.org/10.1007/s00404011-2147-8

12. Tasci $T$, Turan $T$, Ureyen I, et al. Is there any predictor for residual disease after cervical conization with positive surgical margins for HSIL or microinvasive cervical cancer? J Low Genit Tract Dis 2015;19:115-118. https://doi.org/10.1097/LGT.0000000000000079

13. Monsonego J, Cox JT, Behrens C, et al. Prevalence of high-risk human papilloma virus genotypes and associated risk of cervical precancerous lesions in a large U.S. screening population: data from the ATHENA trial. Gynecol Oncol 2015;137:47-54. https:// doi.org/10.1016/j.ygyno.2015.01.551

14. Gultekin M, Dundar S, Keskinkilic B, et al. How to triage HPV positive cases: Results of four million females. Gynecol Oncol 2020;158:105-111. https://doi. org/10.1016/j.ygyno.2020.04.698

15. Gultekin M, Zayifoglu Karaca M, Kucukyildiz I, et al. Initial results of population based cervical cancer screening program using HPV testing in one million Turkish women. Int J Cancer 2018;142:1952-1958. https://doi.org/10.1002/ijc.31212

16. Cuzick J, Wheeler C. Need for expanded HPV genotyping for cervical screening. Papillomavirus Res 2016;2:112115. https://doi.org/10.1016/j.pvr.2016.05.004

17. Diaz ES, Aoyama C, Baquing MA, et al. Predictors of residual carcinoma or carcinoma-in-situ at hysterectomy following cervical conization with positive margins. Gynecol Oncol 2014;132:76-80. https://doi. org/10.1016/j.ygyno.2013.11.019

18. Fu Y, Chen C, Feng S, et al. Residual disease and risk factors in patients with high-grade cervical intraepithelial neoplasia and positive margins after initial conization. Ther Clin Risk Manag 2015;11:851856. https://doi.org/10.2147/TCRM.S81802
19. Ayhan A, Tuncer HA, Reyhan NH, Kuscu E, Dursun P. Risk factors for residual disease after cervical conization in patients with cervical intraepithelial neoplasia grades 2 and 3 and positive surgical margins. Eur $\mathrm{J}$ Obstet Gynecol Reprod Biol 2016;201:1-6. https://doi. org/10.1016/j.ejogrb.2016.03.021

20. Van der Heijden E, Lopes AD, Bryant A, Bekkers R, Galaal K. Follow-up strategies after treatment (large loop excision of the transformation zone (LLETZ)) for cervical intraepithelial neoplasia (CIN): impact of human papillomavirus (HPV) test. Cochrane Database Syst Rev 2015;1:CD010757. https://doi. org/10.1002/14651858.CD010757.pub2

Etik kurul onayı: Pamukkale Üniversitesi Tıp Fakültesi Girişimsel Olmayan Klinik Araştırmalar Etik Kurulu'ndan 16.04.2020 tarih ve $20 / 26602$ karar sayısı ile yerel etik onayı alındı.

\section{Yazarların makaleye olan katkıları}

D.K. ve T.G. çalışmanın ana fikrini ve hipotezini kurgulamışlardır. D.K. teoriyi geliştirmiş ve T.G, Y.K ve E.A ile birlikte materyel metod bölümünü düzenlemişlerdir. Sonuçlar kısmındaki verilerin değerlendirmesini T.G. yapmıştır. Makalenin tartışma bölümü D.K. ve T.G. tarafından yazıımış, B.K ve E.A gözden geçirip gerekli düzeltmeleri yapmış ve onaylamıştır. Ayrıca tüm yazarlar çalışmanın tamamını tartışmış ve son halini onaylamıştır. 